\title{
AN ANALYSIS OF HOSPITALIZATION INSURANCE SCHEMES
}

\author{
C. E. B. FROST AND AUDREY W. M. WARD \\ Division of Economic Studies, and \\ Medical Care Research Unit, Department of Community Medicine, University of Sheffield
}

An analysis has been made of the liabilities and theoretical surpluses of several profit-making hospitalization insurance schemes, that is, schemes which pay a cash benefit on hospitalization as distinct from sickness and whose benefit is not related to the incurrence of hospital fees. The information required for this study has been obtained from the companies concerned (advertisements and correspondence), the Hospital In-patient Enquiry 1970, and the in-patient statistics from the Mental Health Enquiry for the year 1970. By early 1973 six such schemes had been identified, and these, together with the British United Provident Association (BUPA) Hospital Cash Scheme and two schemes of the British Hospitals Contributory Schemes Association (BHCSA), form the subject matter of this study.

\section{Profit-making Schemes}

Two of the six schemes are offered by the same company, that is, London and Edinburgh General Insurance Co. Ltd. (now known as Mercury Insurance Holdings Ltd.), whose parent company is the International Telephone and Telegraph Corporation. Three more schemes are sponsored by American companies-the Gold Shield scheme of the Life Assurance Company of Pennsylvania, the Hospital Money Plan of the Continental Casualty Company, and the Family Cancer Plan of the American Family Life Assurance Company of Columbus, Georgia. The sixth scheme, Hospital Plan, is not provided by a limited company but is underwritten at Lloyds.

\section{The Non-Profit-MaKing Schemes}

The British United Provident Association, a relative late-comer to the field of hospitalization insurance, announced its scheme in 1972. It is working in partnership with the Clerical Medical and General Life Assurance Society and their scheme is on offer to both existing members of BUPA and others. The constituent members of the BHCSA had in fact been first in the field. After the first world war, when the voluntary hospitals were in severe financial difficulties, their plight was investigated by the Voluntary Hospitals Committee under Viscount Cave (Ministry of Health, 1921). This Committee reported in 1921 and as a result a scheme was laid before the British Hospitals Association. It was accepted that payments to hospitals should take the form of payments for services rendered and that a proportion of the contribution should be set aside for 'extra-hospital benefits'. These provide cash payments for contributors for such diverse purposes as dentures, spectacles, convalescence, attendance at out-patient departments, and maternity.

A typical scheme in the 1930s would cost the subscriber 3d. per week and would pay any hospital in which he was a patient $£ 217 \mathrm{~s}$. 6d. per week. The schemes were limited to those earning less than $£ 6$ per week if married with dependants, and $£ 4$ if single (Hospital Saving Association, 1936). With the coming of the National Health Service in 1948 the original purposes of the schemes, support for the hospitals and insurance against hospital fees, disappeared. However, a number of schemes whose funds were not tied to particular hospitals survived to form the present BHCSA (founded in 1948). These generally provide cash payments for contributors on being admitted to hospital, in addition to the extra hospital benefits mentioned above (Tables I and II).

\section{Method of ANALYsis}

It was decided to examine the commercial and some of the non-profit-making schemes, and to compare the relative benefits obtainable for a number of typical household units of a given size and age structure. The tables of the Hospital In-patient Enquiry for 1970 (HIPE), the Mental Health Enquiry, and the Registrar General's Review for the same year were used to determine the risk that existed of hospitalization in the population as a

continued on page 199 


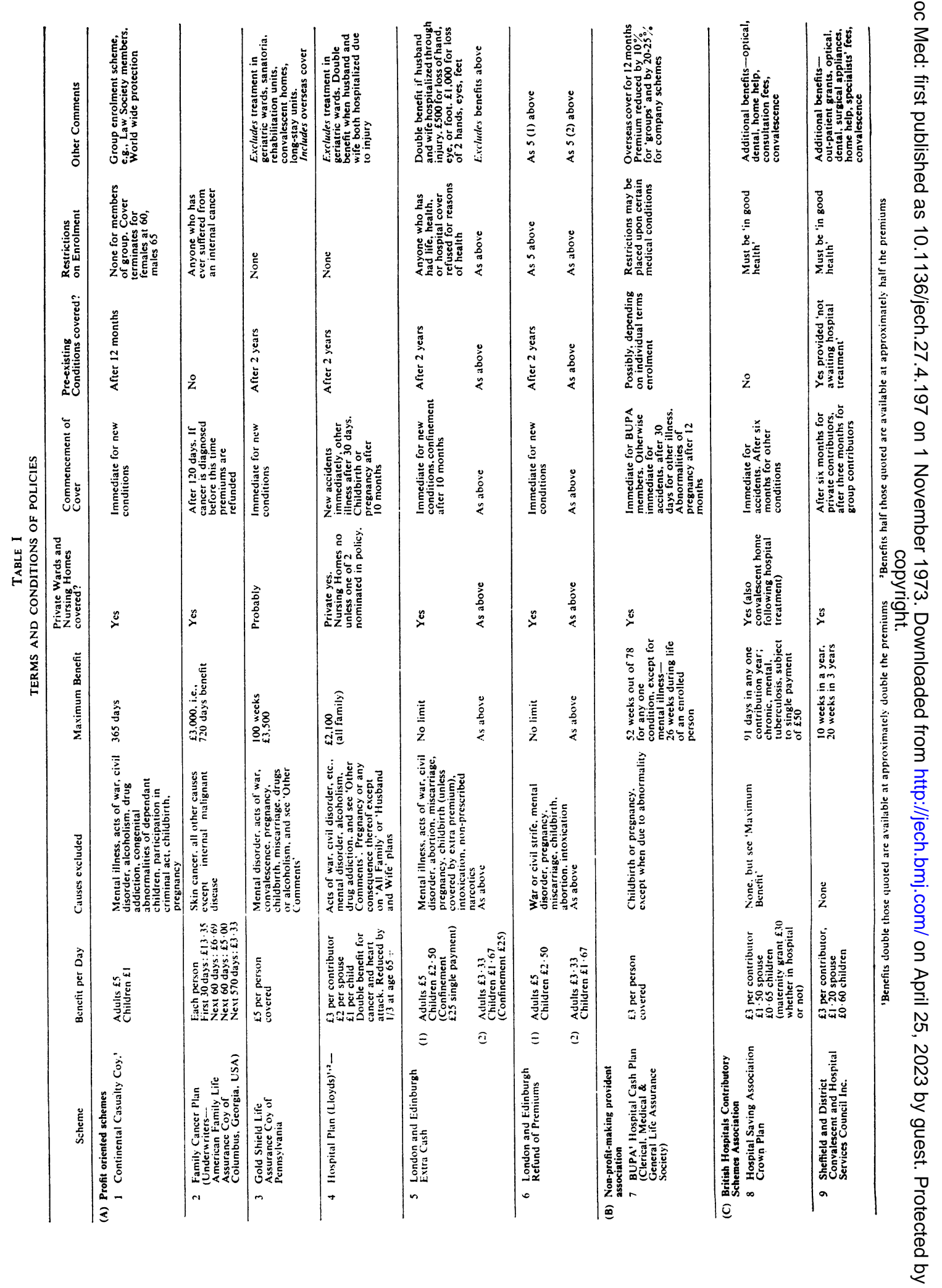


TABLE II

PREMTUMS PER ANNUM

(1) Continental Casualty Co.

\begin{tabular}{|c|c|c|c|c|}
\hline \multirow[b]{3}{*}{$\begin{array}{c}\text { Member's } \\
\text { Age }\end{array}$} & \multicolumn{4}{|c|}{ Premiums per Member of Group (e.g., Law Society) } \\
\hline & \multicolumn{2}{|c|}{ Members only Cover } & \multicolumn{2}{|c|}{ Families Cover } \\
\hline & Male & Female & $\begin{array}{l}\text { Member and } \\
\text { Spouse }\end{array}$ & $\begin{array}{l}\text { Member, } \\
\text { Spouse and } \\
\text { all Children }\end{array}$ \\
\hline $\begin{array}{ll}<35 & \ldots \\
35-44 & \ldots \\
45-54 & \ldots \\
55-64 * & \ldots\end{array}$ & $\begin{array}{c}f \\
7 \cdot 00 \\
9 \cdot 00 \\
14 \cdot 00 \\
28 \cdot 00\end{array}$ & $\begin{array}{c}\mathcal{E} \\
8 \cdot 00 \\
11 \cdot 00 \\
17 \cdot 00 \\
25 \cdot 00\end{array}$ & $\begin{array}{c}f \\
15 \cdot 00 \\
20 \cdot 00 \\
31 \cdot 00 \\
53 \cdot 00\end{array}$ & $\begin{array}{c}\mathcal{E} \\
19 \cdot 80 \\
24 \cdot 80 \\
35 \cdot 40 \\
56 \cdot 40\end{array}$ \\
\hline
\end{tabular}

- Female cover terminates at age 60

Male cover terminates at age 65

(2) Fammy Cancer Plan

Individual premium $\mathrm{f6}$

Family premium 110 . This covers mother, father, and all unmarried children under 18.

(3) Gold ShIELd

Premiums vary according to age of covered individual at the time of enrolment. No increase with age.

\begin{tabular}{cc}
$\begin{array}{c}\text { Age at Enrolment } \\
\text { of each Individual } \\
\text { Covered }\end{array}$ & $\begin{array}{c}\text { Annual Premium per } \\
\text { Person covered }\end{array}$ \\
\hline & $£$ \\
$0-18$ & $12 \cdot 60$ \\
$19-39$ & $19 \cdot 20$ \\
$40-54$ & $24 \cdot 00$ \\
$55-64$ & $28 \cdot 80$ \\
$65-74$ & $38 \cdot 40$ \\
$75+$ & $50 \cdot 40$
\end{tabular}

(4) Hosprtal Plan

\begin{tabular}{lc} 
& $\begin{array}{c}\text { Annual Premiums, } \\
\text { All Ages }\end{array}$ \\
\hline Individuals & $\ldots$ \\
Husband and wife.. & $18 \cdot 00$ \\
All family* & $33 \cdot 00$ \\
One-parent family.. & 47.40 \\
& 33.00
\end{tabular}

- All family, i.e., husband, wife, and all children under 18 unmarried and living at home. New babies from age 3 months.

(5) London and Edingurgh: Extra Cash Plan

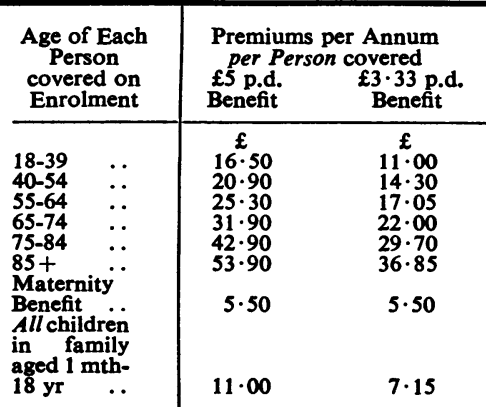

These premiums are increased by one eleventh if they are paid monthly, and do not increase with age after enrolment.
(6) London and Edinburgh: Refund of Premtum Plan

\begin{tabular}{|c|c|c|}
\hline \multirow{2}{*}{$\begin{array}{l}\text { Age of Each } \\
\text { Person } \\
\text { covered on } \\
\text { Enrolment }\end{array}$} & \multicolumn{2}{|c|}{$\begin{array}{l}\text { Premium per Annum per } \\
\text { Person covered on enrolment }\end{array}$} \\
\hline & $\begin{array}{l}\text { E5 p.d. } \\
\text { Benefit }\end{array}$ & $\begin{array}{l}\text { £3.33 p.d. } \\
\text { Benefit }\end{array}$ \\
\hline \multirow[t]{2}{*}{$\begin{array}{ll}18-39 & . \\
40-54 & . \\
55-64 & . \\
65-74 & . \\
75-84 & . \\
85+ & . \\
\text { All children } \\
\text { in family } . .\end{array}$} & $\begin{array}{c}f \\
22 \cdot 80 \\
27 \cdot 60 \\
31 \cdot 20 \\
38 \cdot 40 \\
51 \cdot 50 \\
63 \cdot 60\end{array}$ & $\begin{array}{c}f \\
15 \cdot 00 \\
18 \cdot 60 \\
21 \cdot 00 \\
25 \cdot 80 \\
34 \cdot 20 \\
42 \cdot 60\end{array}$ \\
\hline & $13 \cdot 80$ & 9.00 \\
\hline
\end{tabular}

Premiums do not increase with age after enrolment.

(7) BUPA

\begin{tabular}{|c|c|c|}
\hline \multirow{2}{*}{$\begin{array}{l}\text { Age of Each } \\
\text { Person } \\
\text { covered }\end{array}$} & \multicolumn{2}{|c|}{$\begin{array}{l}\text { Premiums per Person } \\
\text { covered per Annum }\end{array}$} \\
\hline & $\begin{array}{l}\text { E6 p.d. } \\
\text { Benefit }\end{array}$ & $\begin{array}{l}\text { £3 p.d. } \\
\text { Benefit }\end{array}$ \\
\hline $\begin{array}{ll}0-17 & \\
18-44 & . \\
45-55 & . \\
60+ & .\end{array}$ & $\begin{array}{c}f \\
9 \cdot 60 \\
14 \cdot 40 \\
19 \cdot 20 \\
31 \cdot 20\end{array}$ & $\begin{array}{r}f \\
4 \cdot 80 \\
7 \cdot 20 \\
9 \cdot 60 \\
15 \cdot 60\end{array}$ \\
\hline
\end{tabular}

Age limit for joining is 60 except for current BUPA members.

(8) hSA Crown Plan

Premium is $£ 13$ per annum per 'contributor', and this covers himself, his wife, and his children aged less than 16 years. The age limit for joining the scheme is 60 years, but contributors may continue in the scheme after that age.

(9) Sheffield and District Convalescent and Hosprtal Services COUNCIL

Premium is $£ 5.20$ per annum per 'contributor'; this covers himself, his dependent wife, and dependent children under 18 years residing with the contributor. 'Dependent' means not normally employed. Age limit for joining the scheme is 65 years, but contributors may continue in the scheme after that age.

continued from page 197

whole. The analysis of the liabilities and standardized gross surplus of the various schemes for each household unit is based on the formula given below. It should be noted that this formula does not estimate profit net of administrative costs and tax liabilities.

Standardized gross surplus $=$

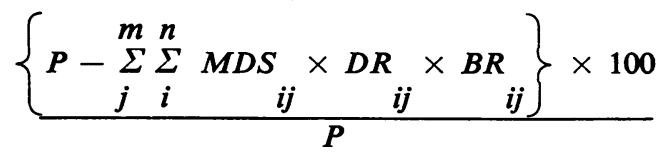

where $\boldsymbol{P}=$ annual premium per subscriber

$$
\begin{aligned}
& M D S=\text { mean duration of stay (spell) } \\
& D R=\text { annual discharge rate } \\
& B R=\text { benefit rate }
\end{aligned}
$$

for $i^{\text {th }}$ eligible cause and $j^{\text {th }}$ member of the household unit. 
The standardized gross surplus used to compare the schemes is obtained by multiplying for an eligible cause the mean duration of stay $(M D S)$ by the discharge rate $(D R)$, which gives the annual bed days per person. This multiplied by the benefit rate $(B R)$ gives the benefit liability $(B L)$. These calculations are repeated for all relevant causes for each of the persons covered. If we subtract the total benefit liability from the premium $(P)$ we obtain the gross surplus. This multiplied by 100 and divided by the premium gives the standardized gross surplus for an annual premium of $£ 100$ (for a worked example see Appendix 3).

The mean duration of stay in the HIPE tables is based on patient-spells in hospital, not on the length of time spent in hospital by individual patients. For example, a patient who had three spells in hospital in one year of 4,10 , and 11 days would be represented in the HIPE tables (e.g., table 9):

(1) by adding 25 days to the total number of days spent in hospital to be distributed over three spells (if there were no other spells to be accounted for in his age, marital status, and diagnostic grouping, we would therefore observe a mean duration of stay (spell) for this group of $8 \cdot 3$ ), and

(2) by adding three more discharges to the number recorded. Continuing our example mentioned under (1), the discharge rate would be $(3 / Y) \times 10,000$ where $Y$ is the total number of people in England and Wales in the age/marital status cohort under consideration.

Most schemes, however, place an upper limit on their liability to the subscriber or an insured member of the household unit. For this reason the calculation of the theoretical liability of the scheme for each eligible cause will tend to overestimate the actual liability.

The Mental Health Enquiry statistics, on the other hand, do enumerate the actual patients but do not differentiate by marital status. Therefore the annual bed-days spent in psychiatric hospitals for each individual cannot be calculated by $\sum_{i}^{n} M D S \times D R$, and the following method has been used instead:

Annual bed-days in psychiatric hospitals per person

$$
=\frac{N H \times M \times 365}{N P}
$$

where $N H=$ number of people in this age/sex group in psychiatric hospitals or units on 31 December 1970 whose stay is less than one year

$$
\begin{aligned}
M= & \text { percentage of } \mathrm{NH} \text { of given marital } \\
& \text { status in psychiatric beds in 'other' } \\
& \text { units in this age/sex category } \\
N P= & \text { number of people in this age/sex/ } \\
& \text { marital status group in the whole } \\
& \text { population. }
\end{aligned}
$$

( $M$ is derived in the absence of information to the contrary on the assumption that the proportion of married and unmarried is the same in psychiatric hospitals and units as among those being treated for psychiatric illness in general wards.)

All schemes known to us which do pay a benefit for mental disorder will not effectively accept liability for a stay of longer than one year. It is for this reason that $\mathrm{NH}$ refers to the number of people in psychiatric hospitals whose stay is less than one year. It can be seen that even this statistic will overestimate the theoretical liability because the maximum benefit allowed by any scheme is 26 weeks in any one year. Unfortunately, HIPE does not permit such an allowance to be made for patients with mental disorder whose stay is in a general hospital.

As both HIPE and the Mental Health Enquiry provide data only for relatively comprehensive ageo groups, linear interpolation has been used to calculate the liability of a scheme for a particular household unit (see Appendix 1). Most schemes exclude certain conditions, especially mental disorder and pregnancy (see Table I and Appendix 2). This has been allowed for in the tables. Two schemes (Hospital Plan and Gold Shield) exclude all patients in geriatric wards. At the same time Hospital Plan offers double benefits for patients with cancer or heart attack. We are informed, however, that patients with heart attack or cancer who happen to be placed in geriatric wards are excluded from benefits. Our data do not allow this condition to be taken into account. Pre-existing illness, variously defined, is excluded from several schemes either for a period or altogether. This cannot becalculated exactly and so has been ignored, as have the exclusions for alcoholism and drug addiction. The effect of ignoring these exclusions is to make the calculated resultant gross profit appear rather lower than it actually is in practice.

\section{Estimates of Standardized Gross Surplus}

It can be seen from Tables III and IV that all schemes make a considerable profit on subscribers who are less than 35 on entry (assumed to be the male in the case of a family), except for the Sheffield and District scheme, and even here its only loss is for families where the male's age ranges from 20 
TABLE III

STANDARDIZED GROSS SURPLUSES FOR SINGLE PERSONS

\begin{tabular}{|c|c|c|c|c|c|c|c|c|c|c|}
\hline $\begin{array}{c}\text { Age } \\
\text { (yrs) }\end{array}$ & Sex & $\begin{array}{c}\text { Continental } \\
\text { Casualty }\end{array}$ & $\underset{\text { Cancer }}{\ddagger}$ & Shold $^{\S}$ & $\underset{\text { Plan }}{\text { Hospital }}$ & $\begin{array}{c}\text { \& } \\
\text { London \& } \\
\text { Edinburgh } \\
\text { Extra Cash } \\
\text { Plan }\end{array}$ & $\begin{array}{l}\quad \$ \\
\text { London \& } \\
\text { Edinburgh } \\
\text { Refund of } \\
\text { Premiums }\end{array}$ & $\begin{array}{c}\text { BUPA } \\
\text { Hospital } \\
\text { Cash }\end{array}$ & $\begin{array}{c}\text { HSA } \\
\text { Crown } \\
\text { Plan }\end{array}$ & $\begin{array}{l}\text { Sheffield } \\
\& \text { DHCSC }\end{array}$ \\
\hline $20-24$ & $\underset{\mathbf{F}}{\mathbf{M}}$ & $\begin{array}{l}67 \cdot 54 \\
69 \cdot 24\end{array}$ & $\begin{array}{l}98 \cdot 68 \\
99 \cdot 01\end{array}$ & $\begin{array}{l}88 \cdot 17 \\
87 \cdot 19\end{array}$ & $\begin{array}{l}92 \cdot 32 \\
86 \cdot 98\end{array}$ & $\begin{array}{l}86 \cdot 23 \\
85 \cdot 08\end{array}$ & $\begin{array}{l}90 \cdot 03 \\
89 \cdot 21\end{array}$ & $\begin{array}{l}70 \cdot 88 \\
66 \cdot 70\end{array}$ & $\begin{array}{l}89 \cdot 01 \\
81 \cdot 17\end{array}$ & $\begin{array}{l}59 \cdot 67 \\
42 \cdot 20\end{array}$ \\
\hline $25-34$ & $\begin{array}{l}\mathbf{M} \\
\mathbf{F}\end{array}$ & $\begin{array}{l}52.73 \\
50.69\end{array}$ & $\begin{array}{l}97 \cdot 51 \\
96 \cdot 48\end{array}$ & $\begin{array}{l}82 \cdot 77 \\
79 \cdot 45\end{array}$ & $\begin{array}{l}88 \cdot 72 \\
82 \cdot 60\end{array}$ & $\begin{array}{l}79.95 \\
76.09\end{array}$ & $\begin{array}{l}85 \cdot 48 \\
82 \cdot 69\end{array}$ & $\begin{array}{l}41 \cdot 62 \\
43 \cdot 44\end{array}$ & $\begin{array}{l}84 \cdot 43 \\
89 \cdot 39\end{array}$ & $\begin{array}{r}19 \cdot 25 \\
8 \cdot 50\end{array}$ \\
\hline $35-44$ & $\begin{array}{l}\mathbf{M} \\
\mathbf{F}\end{array}$ & $\begin{array}{l}45 \cdot 95 \\
19 \cdot 75\end{array}$ & $\begin{array}{l}92 \cdot 89 \\
82 \cdot 54\end{array}$ & $\begin{array}{l}77 \cdot 49 \\
59 \cdot 13\end{array}$ & $\begin{array}{l}82 \cdot 67 \\
67 \cdot 24\end{array}$ & $\begin{array}{l}73 \cdot 99 \\
52 \cdot 79\end{array}$ & $\begin{array}{l}81 \cdot 57 \\
66 \cdot 55\end{array}$ & $\begin{array}{r}23 \cdot 79 \\
-4 \cdot 52\end{array}$ & $\begin{array}{l}78 \cdot 40 \\
55 \cdot 19\end{array}$ & $\begin{array}{r}-5 \cdot 52 \\
-49 \cdot 26\end{array}$ \\
\hline $45-64$ & $\begin{array}{l}\mathbf{M} \\
\mathbf{F}\end{array}$ & $\begin{array}{l}34 \cdot 65 \\
57 \cdot 99 *\end{array}$ & $\begin{array}{l}41 \cdot 18 \\
48 \cdot 94\end{array}$ & $\begin{array}{l}67 \cdot 49 \\
80 \cdot 74\end{array}$ & $\begin{array}{l}49 \cdot 10 \\
68 \cdot 73\end{array}$ & $\begin{array}{l}40 \cdot 59 \\
61 \cdot 82\end{array}$ & $\begin{array}{l}53 \cdot 32 \\
70 \cdot 00\end{array}$ & $\begin{array}{l}6 \cdot 90 \\
3 \cdot 80\end{array}$ & $\begin{array}{l}39 \cdot 11 \\
58 \cdot 41\end{array}$ & $\begin{array}{l}-98 \cdot 74 \\
-32 \cdot 37\end{array}$ \\
\hline $65-74$ & $\underset{\mathbf{F}}{\mathbf{M}}$ & 二 & $\begin{array}{r}-48 \cdot 05 \\
3 \cdot 43\end{array}$ & $\begin{array}{l}75 \cdot 94 \dagger \\
93 \cdot 4 \dagger\end{array}$ & $\begin{array}{l}40 \cdot 67 \dagger \\
83 \cdot 72 \dagger\end{array}$ & $\begin{array}{r}7 \cdot 83 \\
47 \cdot 53\end{array}$ & $\begin{array}{l}23 \cdot 43 \\
56 \cdot 43\end{array}$ & $\begin{array}{r}-30 \cdot 00 \\
23 \cdot 15\end{array}$ & $\begin{array}{r}-34 \cdot 82 \\
22 \cdot 08\end{array}$ & $\begin{array}{r}-290 \cdot 00 \\
-130 \cdot 54\end{array}$ \\
\hline $75+$ & $\begin{array}{l}\mathbf{M} \\
\mathbf{F}\end{array}$ & - & $\begin{array}{l}-96 \cdot 37 \\
-11 \cdot 10\end{array}$ & - & - & $\begin{array}{r}-29 \cdot 37 \\
-2 \cdot 51\end{array}$ & $\begin{array}{r}-9 \cdot 78 \\
13 \cdot 77\end{array}$ & $\begin{array}{r}-130.95 \\
-98.11\end{array}$ & $\begin{array}{l}-160 \cdot 20 \\
-104.99\end{array}$ & $\begin{array}{l}-610 \cdot 68 \\
-494 \cdot 34\end{array}$ \\
\hline
\end{tabular}

TABLE IV

STANDARDIZED GROSS SURPLUSES FOR HOUSEHOLDS

\begin{tabular}{|c|c|c|c|c|c|c|c|c|c|c|c|}
\hline \multicolumn{2}{|c|}{$\begin{array}{c}\text { Age of Male } \\
\text { Subscriber } \\
\text { (years) }\end{array}$} & $\begin{array}{l}\text { Ages of Other } \\
\text { Members of } \\
\text { Household }\end{array}$ & $\begin{array}{l}\text { Continental } \\
\text { Casualty }\end{array}$ & $\begin{array}{l}\text { Family* } \\
\text { Cancer }\end{array}$ & $\begin{array}{l}\text { Gold } \\
\text { Shield }\end{array}$ & $\begin{array}{c}\text { Hospital } \\
\text { Plan }\end{array}$ & $\begin{array}{c}\text { London \& } \\
\text { Edinburgh } \\
\text { Extra Cash } \\
\quad \text { Plan }\end{array}$ & $\begin{array}{l}\text { London \& } \\
\text { Edinburgh } \\
\text { Refund of } \\
\text { Premium }\end{array}$ & $\begin{array}{c}\text { BUPA } \\
\text { Hospital } \\
\text { Cash }\end{array}$ & $\begin{array}{c}\text { HSA } \\
\text { Crown } \\
\text { Plan }\end{array}$ & $\begin{array}{l}\text { Sheffield } \\
\text { \& DHCSC }\end{array}$ \\
\hline $22 \cdot 5$ & $\ldots$ & F20.5 & $76 \cdot 26$ & $98 \cdot 71$ & 90.57 & $78 \cdot 13$ & $89 \cdot 21$ & $92 \cdot 19$ & $80 \cdot 18$ & $57 \cdot 39$ & -0.57 \\
\hline 30 & . & $\begin{array}{l}\text { F28 } \\
\text { B5 } \\
\text { G3 }\end{array}$ & $71 \cdot 41$ & 96.04 & $81 \cdot 28$ & 87.04 & $81 \cdot 72$ & $86 \cdot 46$ & $79 \cdot 82$ & $64 \cdot 64$ & $8 \cdot 04$ \\
\hline 40 & . & $\begin{array}{l}\text { F38 } \\
\text { B15 } \\
\text { G13 }\end{array}$ & $72 \cdot 96$ & $90 \cdot 25$ & $85 \cdot 88$ & $90 \cdot 41$ & $83 \cdot 28$ & $87 \cdot 44$ & $83 \cdot 51$ & $73 \cdot 53$ & $20 \cdot 42$ \\
\hline 55 & .. & F53 & $78 \cdot 76$ & $61 \cdot 12$ & $80 \cdot 49$ & $81 \cdot 12$ & $75 \cdot 31$ & $80 \cdot 68$ & $80 \cdot 42$ & $62 \cdot 93$ & $-12 \cdot 35$ \\
\hline 70 & .. & F68 & - & $10 \cdot 12$ & 86.61 & $87 \cdot 41$ & $63 \cdot 15$ & $69 \cdot 47$ & $74 \cdot 63$ & $38 \cdot 60$ & $-119 \cdot 96$ \\
\hline
\end{tabular}

*Family Cancer Plan based on maximum benefit only

to 24. The loss of $-\mathfrak{f 0 . 5 7}$ is explained because this scheme admits pregnancy as an eligible cause. The standardized gross surplus ranges from $£ 99.00$ for single females aged 20-24 in the Family Cancer Plan to $£ 41.62$ for single males aged 25-34 in BUPA. Most of the commercial schemes make a profit on the subscribers aged over 35 ; but the surplus varies greatly, the highest being $+£ 92 \cdot 89$ (Family Cancer Plan, single males aged 35-44) and the lowest being -£96 · 37 (Family Cancer Plan, single males aged 75+).

It is interesting to note that for nearly every scheme the profit earned per subscriber does fall with an increase in the age of subscribers. To this extent the commercial schemes are countenancing a certain amount of cross-subsidization among age groups. The cross-subsidization implicit in many non-profit-making schemes is especially noticeable in the case of the Sheffield and District scheme. The London-based Hospital Savings Association Crown
Plan manages to avoid a certain amount of crosssubsidization by providing a terminal grant for all causes associated with chronic conditions. Hospital Plan and Gold Shield Plan avoid a certain degree of cross-subsidization by excluding people hospitalized in geriatric wards. As nearly all schemes disallow pre-existing conditions and set an upper limit to the benefit payable, such measures are most likely to discriminate against the elderly and therefore reduce the effective cross-subsidization among age groups. The BHCSA schemes offer considerable benefits to subscribers over and above the in-patient grants. These include grants towards the cost of spectacles, dentures, home helps, etc. This, for instance, in the standard HSA scheme amounts to an extra $50 \%$ of the total benefits paid out for hospitalization (Hospital Saving Association, 1972).

The estimates given above refer to standardized gross surpluses and not to profit margins. 
Administration costs may be estimated to lie in the range of $10 \%$ to $25 \%$, but it is not possible to be more precise as their fixed-cost element expressed as a percentage of premiums will vary according to the number of subscribers enrolled. The Sheffield and District scheme claim 145,000 subscribers (Sheffield and District Hospital and Convalescent Services Council Inc., 1972). London and Edinburgh and Hospital Plan managements claim 50,000 each (Ennis, 1973). It is reasonable to argue that there are economies of scale available to Sheffield and District which are not available to London and Edinburgh and Hospital Plan. Sheffield and District's administrative costs have fallen from $24.9 \%$ in 1957 , when its membership was 27,177 , to $11.3 \%$ when its membership in 1972 was 145,000 (Sheffield and District Hospital and Convalescent Services Council Inc., 1972). Therefore more of the standardized gross surplus will be required to cover administrative costs for the two commercial schemes than for the Sheffield and District scheme.

The BHCSA schemes enjoy a tax advantage in that they have mutual status as non-profit-making organizations which do not pay tax on their excess of premium income over expenditure provided they conform to the limits prescribed in Sect. 345 of the Income and Corporation Taxes Act 1970. They do, however, pay tax on their investment income, and their advantage would be lost should they have a deficit.

One of the London and Edinburgh schemes offers a refund of premiums for an insured member if no claim is made within a 10 -year period. The premiums for this scheme are among the highest we have discovered, and if an individual single man in the 25-34 age cohort were to invest his premiums to yield $5 \%$ real growth the present value of the annual premiums of $£ 22.80$ invested would be $£ 176.05$ $(=22.80 \times 7.72173$, where 7.72173 is the present value of a 10-year annuity of $£ 1$ ). This compares with $£ 139.97$, which is the present value of the premiums on being refunded after a claim-free period. This latter figure, however, should be weighted by the probability of a given individual not being hospitalized over the 10 -year period. We did not have access to record linkage data which would allow calculation of the probability of not being hospitalized. We have estimated this indirectly from age, sex, and marital status specific discharge rates. Such an estimate cannot take account of the influence for an individual of his previous medical history.

The calculation of the expected value of the scheme to an individual was completed by weighting the present value of the benefits which he receives when hospitalized by the probability of being hospitalized. The expected value of the total refunded over a 10-year period for a single man in the $25-34$ age range is $£ 108 \cdot 40$.

Obviously this calculation is only illustrative from the point of view of an individual because it makes no allowance for his conditional probability deviating from that of the whole cohort. Also no allowance has been made for changes in medical practice or morbidity over the 10 -year period. The same figures, however, when related to a scheme which has enrolled a broad cross-section of the community from this particular age-cohort, would yield a standardized gross surplus of $£ 38.42$ for a series of 10 annual premiums of $£ 100$. This figure should be compared with the one derived in Table III of $£ 85 \cdot 48$. For a full explanation of how these estimates were arrived at see Appendix 4.

\section{Discussion}

Considerable doubts about the profit-making schemes have been voiced recently in the national press, and in March 1973 Michael Cocks, Member of Parliament for Bristol South, introduced a Bill under the 10-minute rule 'to prohibit insurance companies from offering cash payments foto hospitalization only, rather than the full period of the illness suffered; and to require insurance companies advertising health or illness policies to publish prominently with such advertisements sufficient actuarial and other relevant information to enable the general public to reach a reasonable judgment on the value of such policies' (Hansard, 1973). This Bill has not been given a second reading. From an individual's point of view hospitalization benefit schemes can be criticized on two counts:

(a) the schemes are unsatisfactory because they do not meet the true costs of illness, and

(b) leaving aside the fact that benefit is related to the length of stay in hospital and not to the length of illness, current medical practice is changing over time in such a way that a scheme's perceived benefit will almost certainly be less than the actual benefit.

As far as (a) is concerned, a distinction must be drawn between individuals seeking cover who are working or fully employed looking after dependants and those who are not. Both have got to meet certain small costs associated with a spell in hospital-extra comforts, new pyjamas, etc. Little evidence is available as yet on the total costs to the patient of a spell in hospital (the results of the forthcoming St. Thomas's Hospital study will provide much needed evidence on this matter). The major cost 
faced by the former group is the loss of potential earnings. These may be quite considerable, especially if the individual depends solely on State-operated contributory schemes. For a worker with a wife and two dependent children taking home $£ 40$ a week the drop in earnings would be of the order of $30 \%$. In the case of those who are looking after dependants (children, elderly relatives, etc.) the main cost associated with illness is the cost of finding suitable substitutes to look after the family. In each group, however, incapacitation may not require a stay in hospital, and even if it does, the stay in hospital may be relatively short compared with the total length of the illness. Days spent in hospital for men of working age account for less than one thirteenth of all certified sickness absence.

Those who do not have these responsibilities are mainly retired people and pensioners for whom the financial costs of illness may not be considerable. If illness does result in hospitalization the costs to be met may still be quite negligible as most pensions will be paid regardless of the place of treatment, the exceptions being supplementary pension and retirement or widow's pension. Supplemenary pension will be stopped immediately the patient enters hospital, and retirement or widow's pension will be stopped after a stay of longer than six weeks in hospital. The main cost which has to be met by pensioners is the fixed cost associated with keeping a home together. The point at issue, however, is that the majority of pensioners live at income levels considerably below the average for those of working age. For this reason a pensioner in receipt of the benefits on offer would most probably enjoy an increase in income while in hospital. In a real sense, therefore, the schemes cannot be considered as providing insurance against a quantifiable loss but rather as a means of gambling for the elderly. See (b) below.

Two final points may be made in connection with (a). Most schemes are sufficiently inflexible with regard to the scale of benefits on offer to necessitate someone who wishes to maintain a certain income level to search among the different schemes rather than pay a different scale of premiums. (The chief exception is London and Edinburgh which does allow subscribers to pay half or double the premiums normally quoted for approximately half or double the benefits.) Secondly, the exclusion of certain causes by most schemes serves to reduce the value of the insurance on offer (and to increase the prospect of the scheme becoming a 'gamble').

The second main criticism (b) arises from the fact that the mean length of hospital stay (for all causes) has declined from 20.1 days in 1951 to 13.9 in 1971 (Figure). The total number of hospital beds is about

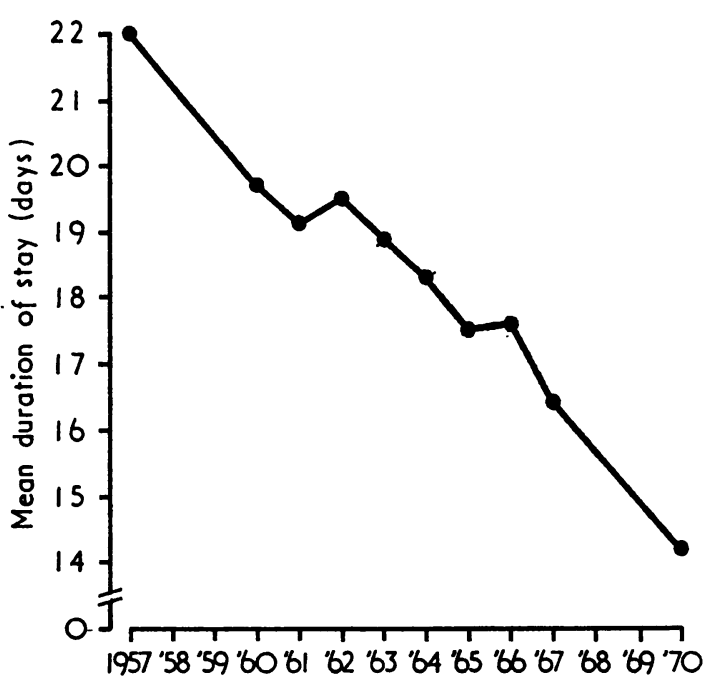

FIGURE Mean duration of stay, males, all causes except psychiatry, England and Wales, 1957-70.

the same as in 1948 when the total population of England and Wales was $10 \%$ smaller. This does not necessarily reflect a decrease of morbidity but a change of policy in favour of reducing the length of stay. This is shown by the fact that hospitalization rates per 10,000 males went up from 668 to 780 between 1957 and 1967. It is to be noted that English lengths of stay are still above North American levels. The public's conception of the risk of being hospitalized almost inevitably will be related to the situation ruling sometime in the past (if indeed it does relate to anything measurable).

HIPE makes it clear that regional differences in lengths of stay and discharge rates are still clearly observable. To the extent that the national figures are brought more closely in line with the lowest regional figures now prevailing, it is clear that actual benefit liability of a scheme will be reduced over time. The difference between the public's perception of its hospitalization risk and the actual risk involved must largely account for the high profitability of the commercial schemes. Even though it has been argued that current medical practice favours fewer spells of shorter duration, it must be allowed that an element of extra demand for hospital beds might be generated by some patients (especially those of pensionable age) who would receive considerable cash payments if in hospital, but not if they were sick at home. This danger has been noted by the British Medical Association in its rejection of any such scheme for its own members. To the extent that this extra demand does appear it will put more pressure on the rationing process for hospital beds. 
One further point needs to be considered: the advantage to the patient of extra benefit for hospitalization due to cancer is questionable. Enquiries have shown that doctors do not generally tell their patients this diagnosis but cloak it in euphemisms. In a recent enquiry it was discovered that in only $13 \%$ of a series of 279 people who died of cancer did the doctor discuss the diagnosis with the patient (Ward, 1973).

An interesting legal point arises here. Does a doctor whose patient has cancer and who would be able to claim extra benefits if hospitalized owe a duty to the patient to inform him of his condition? Lord Justice Edmund Davies, speaking extrajudicially (1973), has suggested that while generally no duty to inform a patient of his condition exists, nevertheless there may be circumstances in which ..... he is legally obliged to tell ..... the whole truth and nothing but the truth'. He was speaking of cases in which patients might make certain property dispositions dependent on the doctor's diagnosis, but the present case appears to be analogous.

\section{CONCLUSION}

It is possible to gain some idea of the profits of the commercial schemes from the gross surpluses. These are over $90 \%$ for some groups, and even with an administrative cost of $20 \%$ are still substantial. The estimates of gross surplus we have given are not based on the returns of the companies themselves but on the assumption that their subscribers are a fair cross-section and that their hospitalization pattern conforms to the average. It may be argued that given the current level of premiums the commercial schemes need a healthy surplus on their younger subscribers to cover the deficits which are incurred with older age groups. It might be maintained, therefore, that if the schemes were assessed over the lifetime of the subscriber the present value of the standardized year surplus would yield a rate of profit which is more normal for the insurance industry. In fact, for a single man who enrols at the age of 20 for 49 years, the present value (at a $5 \%$ rate of interest) of the commercial scheme's standardized gross surplus income stream ranges from $£ 909.63$ to $£ 1490 \cdot 60$ (see Table V).

Another variant of this argument would admit that the profits are above normal taken over the lifetime of an individual, but would maintain that the current level of premiums is justified because of the element of self-selection. In other words, schemes are not likely to enrol a random sample of the entire population but rather a biased sample which includes more high-risk groups than normal, e.g., the elderly and the unmarried. The experience of some of the BHCSA schemes contradicts this view. For instance, the HSA scheme, according to our calculations shows a relatively small theoretical profit, or even deficit on some groups, and yet its publishec accounts are in a healthy state (Hospital Saving Association, 1972). On this basis it would seem that if the actual profits of the commercial scheme were known they could be considerably higher. The interesting question which remains to be answered is why other insurance companies do not join the market. It is usually argued that competition among insurance companies serves to drive down profit rates, and yet this does not appear to have happened

TABLE V

PRESENT VALUE OF STANDARDIZED GROSS SURPLUS FOR A SINGLE MAN OVER AGE SPAN 20-69

\begin{tabular}{|c|c|c|c|c|c|c|c|c|}
\hline & $\begin{array}{c}\text { Continental } \\
\text { Casualty } \\
\text { (to age 65) }\end{array}$ & $\begin{array}{l}\text { Family } \\
\text { Cancer } \\
\text { Plan }\end{array}$ & $\begin{array}{l}\text { Gold } \\
\text { Shield }\end{array}$ & $\begin{array}{c}\text { Hospital } \\
\text { Plan }\end{array}$ & $\begin{array}{c}\text { London \& } \\
\text { Edinburgh } \\
\text { Extra Cash } \\
\text { Plan }\end{array}$ & $\begin{array}{c}\text { BUPA } \\
\text { Hospital } \\
\text { Cash } \\
\text { Plan }\end{array}$ & $\begin{array}{c}\text { HSA } \\
\text { Crown } \\
\text { Plan }\end{array}$ & $\begin{array}{c}\text { Sheffield } \\
\text { and } \\
\text { District }\end{array}$ \\
\hline $\begin{array}{l}\text { Present } \\
\text { value of } \\
\text { income } \\
\text { stream }\end{array}$ & $\begin{array}{c}909 \cdot 63 \\
(955 \cdot 11)\end{array}$ & $\begin{array}{c}1490 \cdot 60 \\
(1565 \cdot 13)\end{array}$ & $\begin{array}{c}1236 \cdot 24^{*} \\
\left(1298 \cdot 05^{*}\right)\end{array}$ & $\begin{array}{c}1443 \cdot 82 \\
(1516 \cdot 01)\end{array}$ & $\begin{array}{c}1153 \cdot 18^{*} \\
\left(1210 \cdot 84^{*}\right)\end{array}$ & $\begin{array}{c}657 \cdot 98 \\
(690 \cdot 88)\end{array}$ & $\begin{array}{c}1314 \cdot 53 \\
(1380 \cdot 26)\end{array}$ & $\begin{array}{c}-148 \cdot 81 \\
(-156 \cdot 25)\end{array}$ \\
\hline
\end{tabular}

SOURCE: Table III, except for figures marked *, in which case the standardized gross surplus has been recalculated on the assumption that the premium rates are maintained at the rate appropriate to the year of entry.

Assumptions: (1) A rate of interest of $5 \%$ has been assumed.

(2) The figures in parentheses are derived on the assumption that the premiums are paid at the beginning of the year; the unbracketed figures are based on the assumption that the premiums are paid at the year-end.

INTERPRETATION

Unlike life assurance, when a company contracts with a policy holder to offer cover at the rate quoted on the policy unless the policy holde cancels the policy, hospitalization insurance is offered on the basis that premium and benefit rates are open to negotiation each year. Two managements, however, do offer a concession to existing subscribers, which is that they can renew their policies at the current rate for their

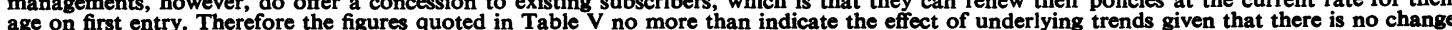
in morbidity, medical practice, premium, and benefit rates. That is to say, the figures represent merely an extrapolation into the future based in morbidity, medical practice, premium, and benefit rates. That is to say, the figures represent merely an extrapolation into the future based on current trends and policy. The management of each scheme can, therefore, alter
the present value of each policy and hence the overall profitability of the scheme. . 
in this case. Is it due to the exercise of moral restraint on the part of the other companies? It must be noted, however, that more competitive rates leading to the enrolment of more people cannot necessarily be regarded as being 'a good thing' in the national context, because it may increase the demand for hospital beds.

The demand for these schemes may reflect attitudes and beliefs which are not necessarily appropriate today. As we have seen, the benefits to be gained on hospitalization are minimal compared with the total costs to the patient of illness-most of which occurs outside hospital.

We have already noted that for some (if not all) households the benefits payable could overcompensate them for the financial loss associated directly with the period of hospitalization. For this reason there will be an inducement for the insured to make an additional claim on the supply of scarce hospital beds. This feature raises an important issue as far as the National Health Service is concerned, especially at a time when the supply of hospital beds per head of the population is falling. This factor cannot be estimated on the basis of current data but would require further investigation.

Although this paper concentrates on commercial schemes, the non-profit-making BHCSA is now moving into areas of comparable benefits and their role may need to be re-assessed. Sir Keith Joseph, speaking at Wolverhampton in September 1971, suggested, for instance, that the areas of greatest need were no longer the acute but the chronic and geriatric patients (BHCSA, 1972). There may be a case for enquiring into the schemes as a whole, bearing in mind the changed circumstances of the seventies. The members of BHCSA could, of course, extend their existing schemes to provide insurance for the full length of illness.* A more radical alternative would be to introduce contributory schemes whose specific aim would be to extend provision of community care for non-acute conditions.

\footnotetext{
* At least one BHCSA scheme-the Bristol Contributory Welfare Association-offers a cash benefit of $£ 3$ per week for the contributor only for certificated illness at home payable from the fourth day of absence from work up to a maximum of the first 13 weeks of illness (after which $£ 1.50$ per week is payable for the second 13 weeks of illness). The subscription is $30 \mathrm{p}$ weekly, which also entitles the contributor (and his spouse) to various other cash benefits including hospitalization benefit. Another scheme-Merseyside Hospitals Council-is also preparing to introduce benefit for illness at home in October 1973 (Dodd, 1972). It is also interesting to note that the Bristol scheme offers attractive daily cash benefits for in-hospital stays (up to $£ 7.14$ for subscribers seeking cover for themselves alone for a weekly subscription of 20p). These cash benefits are payable only for stays of three days or more, an important limitation, as this accounts for one-tenth of patient spells, according to HIPE.
}

\section{SUMMARY}

Nine schemes which offer cash benefits on hospitalization have been examined, six commercial (mainly American-based) and three non-profitmaking. The benefits offered, the premiums payable, and the conditions imposed have been analysed together with the probabilities of hospitalization for each group of people at risk. The theoretical gross profits to the operators range from $99 \%$ on a young person entering one of the schemes to a deficit on some of the elderly. The social, financial, and administrative implications of the schemes are considered.

The authors wish to thank those who helped in the preparation of this paper, in particular, Air Vice-Marshal A. A. Case, Professor G. Clayton, Michael Cocks, M.P., Professor J. Knowelden, Adrian Lambourne, Tony Rocca and members of the Department of Community Medicine. Adrian Lambourne also provided invaluable help with Appendix 4. In addition this paper would not have been completed in the time available but for the careful checking of all the tables by Dorothy Bannon.

The Medical Care Research Unit is supported by a grant from the Department of Health and Social Security.

\section{REFERENCES}

ACHeson, E. D., and BARR, A. (1965). Multiple spells of in-patient treatment in a calendar year. Brit. J. prev. soc. Med., 19, 182.

British Hospitals Contributory Schemes AssoCIATION (1972). Twenty-fourth Annual Report 1971-72.

DodD, J. (1972). Hospital cash insurance. Policy Holder Insurance Journal, June.

EdMund Davies, LoRd Justice (1973). The patient's right to know the truth. Proc. roy. Soc. Med., 66, 533.

ENNIS, C. (1973). Hospital-only insurance plans under attack. Med. News, 5, 1.

HANSARD (1973). Vol. 852, no. 77, 17th March 1973. p. 1300.

Hospital Saving Association (1936). Annual Report. - (1972). Annual Report and Statement of Accounts.

Ministry of Health (1921). Voluntary Hospitals Committee. Final Report. (Cave Report). [Cmd 1335] HMSO, London.

Sheffield and District Hospital and Convalescent Services Council InC. (1972). Annual Report and Statement of Accounts.

WARD, A. W. M. (1973). Telling the patient (in preparation). 


\section{APPENDIX 1}

\section{SOURCES OF DATA AND Method of INTERPolation}

\section{TABLES I AND II}

Advertisements placed in the national press, circulars, and communications with the management of the schemes covered.

\section{TABLES III AND IV}

(1) Report on Hospital In-patient Enquiry 1970, Part 1 Tables, HMSO, table 9. Linear interpolation has been used to obtain the statistics for married women and dependent children. In all cases it has been assumed that the typical age of each age group was that of the cell mid-point. Chronic sick have been estimated on the basis of table 12 which does not allow the estimates of bed-days per annum per person to be differentiated according to marital status. Geriatric patients have been treated similarly.

(2) Psychiatric hospitals and units in England and Wales; in-patient statistics from the Mental Health Enquiry for the year 1970. Department of Health and Social Security, Statistical and Research Report Series No. 4. London, HMSO, 1972, Table 4. Linear interpolation was again used to obtain statistics for married women and dependent children. As noted in the text, this source does not allow the estimates of bed-days per annum per person to be differentiated according to marital status. Such figures were obtained by estimating the proportion of a given marital status occupying beds in non-psychiatric hospitals diagnosed as having a mental disorder.

(3) The Registrar General's Statistical Review of England and Wales for the year 1970. Office of Population Censuses and Surveys. London, HMSO, 1972 Part II Tables, Population, Tables A2, A3(a).

APPENDIX 2

Eligible and Ineligible Causes and Conditions

Where named conditions have been excluded from benefit, or treated differently, e.g., by being eligible for double benefit, an adjustment has been made as far as possible in the calculations. In cases when it has not been possible from the Hospital In-patient Enquiry tables to calculate exactly the element concerned, e.g., 'alcoholism', the particular cause has not been excluded from the calculations. This has the effect of over-stating the relevant company's liability and consequently understating its theoretical gross surplus.

\section{'All causes'}

'Cancer'

Heart attack

Tuberculosis

Chronic sick and geriatric

'Drug addiction', 'Narcotics', 'Alcoholism'

Pregnancy and childbirth

Abnormality of pregnancy or childbirth
All diagnostic groupings nos. A1 to A150 in Table 9 of HIPE. Also psychiatric illness in psychiatric hospitals.

(a) Includes 'Mental Disorders' in HIPE A69 to A71.

(b) All patients in psychiatric hospitals as enumerated in Mental Health Enquiry.

Includes all malignant neoplasms (A45-58) and leukaemia (A59).

This is covered by acute myoo cardial infarction (A83a).

HIPE A6 to A10. All tuberculosis? Includes persons in chronic sick and geriatric departments enumerated in Table 12 HIPE. It has not been possible to discover the proportion of chronic sick patients being nursed in other units. Table 12 does not differentiate by marital status; therefore it has been assumed that the spells enumerated are equally divided between married and non-married.

There is no differentiation in the HIPE tables between maliciously self-administered poisons and accidental or iatrogenic intoxication. Consequently these conditions have not been subtracted.

This is assumed to mean Conditions of pregnancy, childbirth and puerperium (A112-A118, Y60Y61).

Includes Toxaemia of pregnancy and puerperium (A112), Haemorrhage of pregnancy and childbirth (A113), Other pregnancy complications (A117a), Other and unspecified abortions (A115), Other complications of childbirth or puerperium (A116, A117b). 
APPENDIX 3

Example of Calculations: Single Women aged 45-64 'Hospital Plan'

\begin{tabular}{|c|c|c|c|c|c|c|c|c|}
\hline Causes & $\begin{array}{c}\text { Mean } \\
\text { Duration } \\
\text { of Stay } \\
\text { (days) (A) }\end{array}$ & $\begin{array}{c}\text { Discharge } \\
\text { Rate per } \\
10,000 \\
\text { Population (B) }\end{array}$ & $\begin{array}{c}\text { Annual Bed Days } \\
\text { per Person } \\
\left(C=A \times B / 10^{4}\right)\end{array}$ & $\begin{array}{c}\text { Benefit } \\
\text { Rate } \\
\text { per Day } \\
\text { (D) }\end{array}$ & $\begin{array}{c}\text { Benefit } \\
\text { Liability } \\
\text { per Annum } \\
(E=C \times D)\end{array}$ & $\begin{array}{c}\text { Premium } \\
\text { per Annum } \\
\text { (F) }\end{array}$ & $\begin{array}{c}\text { Gross Profit } \\
\text { per Person } \\
\text { per Annum } \\
(\mathbf{G}=\mathbf{F}-\mathbf{E}) \\
\end{array}$ & $\begin{array}{c}\text { Standardized } \\
\text { Gross Profit } \\
\text { per Person } \\
(\mathbf{H}=\mathbf{G} \times 100 / \mathrm{F}) \\
\end{array}$ \\
\hline All causes & $21 \cdot 9$ & $829 \cdot 1$ & 1.8157 & - & - & - & - & - \\
\hline $\begin{array}{l}\text { Mental } \\
\text { disorder }\end{array}$ & $41 \cdot 1$ & $12 \cdot 1$ & 0.0497 & - & - & - & - & - \\
\hline $\begin{array}{l}\text { All causes } \\
\text { excludng } \\
\text { Mental } \\
\text { disorder }\end{array}$ & - & - & $1 \cdot 766$ & 3 & $5 \cdot 298$ & - & - & - \\
\hline Cancer & 23.4 & 97.7 & 0.2286 & 3 & 0.6858 & - & - & - \\
\hline $\begin{array}{l}\text { Heart } \\
\text { attack }\end{array}$ & $23 \cdot 5$ & 16.4 & 0.0385 & 3 & 0.1155 & - & - & - \\
\hline $\begin{array}{l}\text { Geriatric } \\
\text { wards** }\end{array}$ & 226.5 & 6.9 & 0.15628 & (3) & $\begin{array}{l}\overline{6.0993} \\
(0.46885)\end{array}$ & - & - & - \\
\hline $\begin{array}{l}\text { All } \\
\text { excluding } \\
\text { geriatric }\end{array}$ & & & & & 5.6304 & 18 & $12 \cdot 3696$ & $68 \cdot 72$ \\
\hline
\end{tabular}

* This calculation is based on the assumption that no cancer or heart attack is treated in geriatric wards. The calculation therefore underestimates the gross profit. Cancer and heart attack have been included in All Causes and again separately because they qualify for double benefits.

\section{APPENDIX 4} The London and Edinburgh Refund of Premium
Scheme

The expected value of the scheme, $\mathrm{E}$, may be expressed by the following expression:

$\mathrm{E}=\sum_{i=1}^{n} \frac{P_{i}}{(1+r)^{i}}-\sum_{j=0}^{n} \operatorname{Pr}\left(h_{j}\right) \operatorname{PV}\left(R_{j}\right)$

where $P_{i}$ is the premium paid in year $i$

$r$ is the rate of interest

$\operatorname{Pr}\left(h_{j}\right)$ is the probability of being hospitalized $j$ years out of $n$

$P V\left(R_{j}\right)$ is the present value of the sums refunded given that the subscriber has been hospitalized for $j$ years out of $n$

$n$ is the number of claim-free years which must elapse before the premiums are refunded $(=10)$

The expected value of the scheme is derived by expressing the premium paid in present value terms and subtracting from this the expected value of the total refunded over the period $n$. The data available do not allow the calculation directly of the second expression on the right-hand side of the expression. If we assume that

(1) the probability of being hospitalized in one year is statistically independent of the probability of being hospitalized in any other year,

(2) the population's morbidity does not change over the $n$ years, and
(3) the scheme has enrolled an unbiassed sample of the population, then

$$
\operatorname{Pr}(h j)=\operatorname{Pr}(h i)^{j} \operatorname{Pr}(\bar{h} i)^{n-j}\left(\begin{array}{l}
n \\
j
\end{array}\right)
$$

where $\operatorname{Pr}(h i)$ and $\operatorname{Pr}(\overline{h i})$ are the probabilities of being or not being hospitalized in year $i$ respectively.

$\operatorname{Pr}\left(h_{i}\right)=\frac{N_{h}}{N P}=\frac{S_{h}}{N P} \cdot \frac{1}{\eta}$

Where $N_{h}$ is the number of persons belonging to the cohort hospitalized in year $i$

$S_{h}$ is the number of spells attributable to the cohort (an estimate of 1.23 was derived from Acheson and Barr (1965))

$\eta$ is the number of spells per patient

$N P$ is the population at risk

If $j=0$ then $R_{o}=\sum_{i=1}^{10} P_{i}$ and hence $P V\left(R_{o}\right)$ may be obtained; if $j \neq 0$ then,

$$
R_{j}=\frac{A B D \times 365 \times \eta \times B R}{S_{h}}
$$

where $A B D$ is the average number of beds used daily for all eligible causes

$B R$ is the benefit rate

$P V\left(R_{j}\right)$ was obtained by assuming that the claims were randomly distributed throughout the 10-year period

E was calculated to be 67.64 for a member of the single male cohort aged 25-34 (given $r=0.05$ ). 